\title{
PENGEMBANGAN SKALA RESILIENSI KELUARGA DENGAN ANAK BERKEBUTUHAN KHUSUS
}

\author{
Christiany Suwartono ${ }^{1}$, Yapina Widyawati ${ }^{2}$ \\ Fakultas Psikologi, Universitas Katolik Indonesia Atma Jaya \\ Jalan Jenderal Sudirman 51, Jakarta 12930 \\ ${ }^{1}$ christiany.suwartono@atmajaya.ac.id; ${ }^{2}$ yapina.widyawati@atmajaya.ac.id
}

\begin{abstract}
Life challenges are not only for individuals, but also faced by a member of a system, such as family. The ability to face this challenge is known as resilience. This reserach aims to develop a family resilience scale to provide instruments for assessment, research and intervention, especially for families who have children with special needs (CSN). The development of this scale involved 41 families who were chosen using accidental sampling technique. The data analyzed through exploratory factor analysis (EFA), proceeded by confirmatory factor analysis (CFA) confirmed that there were three dimensions of family with CSN resilience scale: acceptance, management, and support. This three-factor model fits the data. The three dimensions turned out to measure one construct, the resilience of family with CSN. This scale has high reliability. Thus, family resilience scale of family with CSN has good psychometric properties for further use.
\end{abstract}

Keywords: child with special needs, family resilience, reliability, resilience scale, validity

\begin{abstract}
Abstrak
Tantangan dalam kehidupan tidak hanya dihadapi oleh individu, namun ada pula tantangan yang harus dihadapi oleh individu sebagai anggota sebagai sebuah sistem, misalnya keluarga. Kemampuan dalam menghadapi tantangan ini dikenal dengan istilah resiliensi. Peneliti mengembangkan skala resiliensi keluarga guna menyediakan instrumen untuk penelitian, penilaian dan intervensi, khususnya pada keluarga dengan anak berkebutuhan khusus (ABK). Pengembangan skala ini melibatkan 41 keluarga ABK dengan teknik accidental sampling. Data dianalisis menggunakan exploratory factor analysis (EFA), kemudian confirmatory factor analysis (CFA), yang menunjukkan ada tiga dimensi dari skala resiliensi keluarga $\mathrm{ABK}$, yaitu penerimaan, pengelolaan, dan dukungan. Model tiga dimensi tersebut fit dengan data. Hal ini berarti ketiga dimensi ini terbukti mengukur satu konstruk, yaitu resiliensi keluarga dengan ABK. Dari segi reliabilitas, skala ini memiliki reliabilitas yang tinggi. Dengan demikian, skala resiliensi keluarga ABK memiliki properti psikometris yang baik untuk digunakan lebih lanjut.
\end{abstract}

Kata kunci: anak berkebutuhan khusus, reliabilitas, resiliensi keluarga, skala resiliensi, validitas 


\section{Pendahuluan}

Dalam rentang kehidupan, individu tidak bisa dilepaskan dari masalah atau kesulitan dan tantangan hidup. Namun demikian terdapat perbedaan individual dalam menghadapi berbagai pengalaman dan tantangan tersebut. Ada individu yang tidak mampu bertahan dan tidak mampu menyesuaikan diri dengan baik saat situasi sulit terjadi namun ada yang mampu bertahan, mampu menyesuaikan diri dengan baik dalam menghadapi situasi sulit bahkan terus meningkatkan dirinya meskipun mengalami situasi sulit atau bertumbuh di dalam lingkungan yang tidak mendukung. Kemampuan tersebut dikenal dengan istilah resiliensi. Secara umum, Cicchetti dan Cohen (1995) mendefinisikan resiliensi sebagai kapasitas individu dalam menghadapi tantangan penyesuaian dan pengembangan diri, untuk mencapai hasil yang diinginkan oleh individu (Cicchetti, 1995). Setiap individu dengan berbagai usia dan latar belakang memiliki kapasitas untuk menjadi resilien (Benard, 2004). Penelitian mengenai resiliensi telah banyak dilakukan pada individu yang mengalami berbagai situasi sulit misalnya mengalami bencana alam, hidup di daerah yang mengalami konflik bersenjata, individu dari keluarga yang terpecah (berpisah atau bercerai), dan juga pada keluarga yang memiliki anak berkebutuhan khusus. Di Indonesia, data yang dilansir dari laman resmi Kementrian Pendidikan dan Kebudayaan menyebutkan jumlah anak berkebutuhan khusus tahun 2017 mencapai 1,6 juta anak (Maulipaksi, 2017).

Tantangan tidak hanya dihadapi oleh individu sendiri. Adapula tantangan yang dihadapi oleh keluarga sebagai sebuah sistem. Tantangan bagi orangtua berasal dari tantangan masing-masing anggota keluarga yang mempengaruhi interaksi dalam keluarga, tantangan dari lingkungan keluarga yang lebih besar, lingkungan masyarakat, bahkan tantangan dari kondisi terluar dari keluarga misalnya kondisi sosial ekonomi maupun berbagai tantangan kehidupan. Oleh karena itu, muncul istilah resiliensi keluarga. Walsh (2002), mendefinisikan resiliensi keluarga sebagai proses dalam keluarga untuk mengatasi masalah (coping) dan beradaptasi. Prinsip-prinsip yang mendasari resiliensi keluarga adalah bahwa resiliensi individu paling baik dipahami dan dikembangkan dalam konteks keluarga dan lingkungan sosial yang lebih besar; juga sebagai interaksi antara individu, keluarga, sosiokultural, dan pengaruh institusi (Walsh, 2002).

Kualitas hidup anak berkebutuhan khusus sangat tergantung dari dukungan keluarga (Burgess \& Gutstein, 2007; Frain et al., 2007). Keluarga yang dapat optimal mendukung perkembangan anak dengan kebutuhan khusus adalah keluarga yang resilien, yang mampu beradaptasi dengan situasi yang sulit yang dihadapi oleh anggota keluarga maupun anak dengan kebutuhan khusus tersebut (Cappe, Wolff, Bobet, \& Adrien, 2011; Migerode, Maes, Buysse, \& Brondeel, 2012).

Menurut Walsh (2002), ada tiga elemen utama dari resiliensi keluarga. Elemen pertama, family belief system yaitu saat keluarga memaknai situasi yang tidak menyenangkan. Penerimaan situasi yang tidak menyenangkan menjadi penting bagi keluarga untuk resilien. Keluarga akan mencari pemahaman akan sebab akibat dari peristiwa ini. Penting untuk memperhatikan latar belakang budaya dan agama dari belief yang mendasari atribusi mereka. Selain memaknai peristiwa yang terjadi keluarga juga melihat sesuatu dari sisi positif. Resiliensi menuntut seseorang untuk menerima keterbatasan dari kekuatan yang dimiliki oleh keluarga, memahami situasi apa yang bisa dikontrol dan yang tidak dan melakukan usaha yang optimal (Walsh, 2002). 
Elemen kedua, organizational patterns, dalam keluarga yang resilien terdapat pola organisasi. Kapasitas untuk berubah adalah hal penting dalam keluarga khususnya dalam kondisi penuh tekanan. Ketika keluarga dalam kondisi stres, anggota keluarga punya kebutuhan akan keteraturan. Hal ini diperlukan supaya keluarga merasa aman dan terprediksi tentang apa yang akan terjadi. Kondisi ini dapat membuat keluarga lebih tenang. Dalam keluarga yang berfungsi dengan baik, kepemimpinan cukup terlihat dan jelas, bukan otoriter namun dapat memimpin jalannya keluarga. Dalam elemen ini juga tercakup connectedness, keluarga yang berfungsi dengan baik memiliki anggota keluarga yang saling mendukung. Keluarga saling terikat namun juga menghargai keunikan individu. Keluarga mengusahakan hubungan dan rekonsiliasi dari hubungan antar anggota keluarga. Keluarga besar dan jejaring sosial menyediakan bantuan praktis, dukungan emosional, dan juga informasi (Walsh, 2002).

Elemen ketiga adalah communication process adalah pola dan proses komunikasi dalam keluarga. Kejelasan dalam komunikasi penting untuk berfungsinya keluarga secara efektif. Situasi kemalangan yang sedang dihadapi juga harus diklarifikasi maknanya bagi semua anggota keluarga. Budaya bisa mempengaruhi pola komunikasi dalam keluarga. Komunikasi juga berarti adanya keterbukaan ekspresi emosi. Dalam keluarga yang berfungsi dengan baik, terjadi kehangatan, suasana optimis, kegembiraan dan kenyamanan dalam berelasi. Keluarga dapat berbagi cerita tentang kehidupan baik dengan humor maupun dengan belas kasihan. Hal itu lebih dapat mendekatkan keluarga. Dalam elemen ini juga dibahas adanya kolaborasi dalam pemecahan masalah. Keluarga yang resilien memiliki kemampuan untuk mengatur dan menyelesaikan konflik serta masalah dengan berkolaborasi antar anggotanya. Keluarga perlu mengenali masalah dan mengkomunikasikan pada semua anggota yang terlibat. Curah pendapat secara kolaboratif memungkin keluarga untuk melihat beberapa pilihan, sumber dukungan, dan keterbatasan sehingga dapat memutuskan langkah perencanaan. Keluarga yang berfungsi dengan baik dapat menyelesaikan masalah dengan efisien dan mengambillangkah konkrit (Walsh, 2002).

Tantangan pasti ada di dalam interaksi dan fungsi dalam keluarga (Goldman, 2006; Scorgie, Wilgosh, \& Sobsey, 2004; Seligman, 1997). Di dalam keluarga, juga ada subsistem yang lebih kecil lagi yaitu, suami dan istri, ibu dengan anak atau anak-anak, ayah dengan anak atau anak-anak, dan hubungan persaudaraan antara anak-anak. Subsistem ini memiliki interaksi sendiri yang unik. Hubungan antara suami dengan istri, dan antar anak dapat menjadi lebih baik ataupun juga menjadi buruk ketika situasi yang tidak menyenangkan dan menantang dialami oleh keluarga. Keluarga dengan anak berkebutuhan khusus memiliki tantangan tersendiri. Menurut beberapa penelitian yang pernah dilakukan sebelumnya, keluarga tersebut menunjukkan tingkat stres yang lebih tinggi dibandingkan dengan keluarga lain dan selalu ada tantangan baik secara psikologis maupun fisik (Gupta, 2007; King et al., 2003; Suzuki, Kobayashi, Moriyama, Kaga, \& Inagaki, 2013). Selain tantangan tersebut, keluarga dengan anak berkebutuhan khusus juga mengalami kesulitan dalam hal pendidikan misalnya mendapatkan sekolah yang sesuai dan tantangan dalam menjalankan program intervensi di rumah (Santoso, Ito, Ohshima, Hidaka, \& Bontje, 2015; Schieve, Blumberg, Rice, Visser, \& Boyle, 2007; Suzuki et al., 2013).

Terdapat dua faktor yang berpengaruh mendorong terbentuk atau tidaknya resiliensi yaitu faktor risiko dan faktor protektif (Davis, 1999). Faktor risiko adalah variabel-variabel yang secara langsung dapat memperbesar potensi risiko dan sekaligus meningkatkan probabilitas berkembangnya perilaku dan gaya hidup yang maladaptif. 
Sementara faktor protektif adalah keterampilan dan kemampuan yang sehat yang dikuasai oleh individu yang menjadi pendorong terbentuknya resiliensi pada individu yang bersangkutan. Ketika seseorang harus menghadapi dan mengatasi kesulitan, individu terbantu oleh sumber daya yang dimilikinya. Sumber daya tersebut terbangun melalui beberapa cara (Grotberg, 2003) Cara pertama melalui hubungan dengan orang lain dalam lingkungan seperti orang tua, keluarga, sahabat, guru, tokoh agama, dan komunitas. Cara kedua melalui aktivitas-aktivitas yang dilakukan di sekolah, tempat kerja, dan masyarakat dalam kehidupan sehari-hari. Cara ketiga melalui nilai-nilai, pegangan hidup, dan budaya yang berkembang di lingkungan keluarga dan masyarakat.

Fokus utama dalam penelitian ini adalah sistem ekologi dimana anggota keluarga ada dan mempengaruhi dinamika dalam keluarga. Resiliensi keluarga sangat dipengaruhi oleh sistem ekologi. Salah satunya adalah tentang bagaimana lingkungan mempersepsi anak dengan kebutuhan khusus. Sebagian masyarakat Indonesia percaya bahwa kehadiran anak berkebutuhan khusus dalam keluarga karena karma (Riany, Cuskelly, \& Meredith, 2016). Kepercayaan atau keyakinan tersebut dapat menyebabkan adanya stigma yang bisa membatasi keluarga untuk mencari dan mengakses layanan profesional (Kusumastuti, Pradanasari, \& Ratnawati, 2014).

Dalam kaitannya dengan asesmen resiliensi keluarga, skala untuk mengukur resiliensi keluarga lebih banyak dikembangkan di luar negeri dengan sistem ekologi yang berbeda dengan di Indonesia. Oleh karenanya diperlukan adanya pengembangan skala resiliensi keluarga yang sesuai dengan sistem ekologi di Indonesia, yang diharapkan lebih menggambarkan kondisi di Indonesia. Dengan demikian, penelitian ini bertujuan untuk membuat skala yang dapat mengukur resiliensi keluarga, yang menjadi instrumen bagi penelitian dalam bidang ini selanjutnya. Skala yang disusun juga dapat dipakai sebagai instrumen assessment untuk melakukan intervensi (Walsh, 2002). Skala ini diharapkan dapat digunakan sesuai dengan latar belakang kondisi di Indonesia.

\section{Metode Penelitian}

Penelitian ini melibatkan keluarga-keluarga dengan anak berkebutuhan khusus (ABK). Penelitian dilakukan dengan teknik accidental sampling. Ada 41 keluarga dengan ABK yang menjadi partisipan dalam penelitian ini. Ayah, ibu, dan salah satu saudara dalam keluarga dengan ABK diminta untuk mengisi kuisioner dan skala.

Tahapan dalam penyusuan alat ukur adalah sebagai berikut, pertama perencanaan. Dalam perencanaan dilakukan tujuan pembuatan alat ukur dan target subjek dari alat ukur tersebut. Dalam tahap perencanaan ini juga dilakukan pengidentifikasian dan penentuan domain dari tes dan dilakukan kajian pustaka mengenai konstruk resiliensi. Setelah itu, dilakukan wawancara guna lebih memahami konteks dari subjek alat ukur ini maka dilakukan wawancara pada kelompok target yaitu keluarga dengan anak berkebutuhan khusus. Keluarga yang diwawancara terdiri dari ayah, ibu, dan anak. Selain keluarga, dilakukan survey pada konteks yang lebih luas yaitu masyarakat, dalam hal ini para pengambil kebijakan di pemerintah dan para penyuluh keluarga. Hasil dari kajian pustaka, wawancara, dan survey ini digunakan sebagai bahan dalam pembuatan aitem. Berikut ini merupakan gambaran partisipan dari penelitian ini. 
Tabel 1

Data demografi partisipan.

\begin{tabular}{lllll}
\hline & Gabungan*) & Ayah & Ibu & Saudara \\
\hline Besar sampel (n) & 107 & 39 & 41 & 27 \\
Jenis Kelamin (\%) & & & & \\
Laki-laki & 52.34 & 100.00 & 100.00 & 62.96 \\
Perempuan & 46.73 & & & 33.33 \\
Tidak menjawab & 0.93 & & & 3.70 \\
Pendidikan terakhir (\%) & & & & \\
TK & 0.93 & & & 3.70 \\
SD & 4.67 & & & 18.52 \\
SMP & 7.48 & 20.51 & 29.27 & 29.63 \\
SMA & 26.17 & 5.13 & 14.63 & \\
D3 & 7.48 & 56.41 & 41.46 & 18.52 \\
S1 & 41.12 & 15.38 & 4.88 & \\
S2 & 7.48 & 2.56 & 7.32 & 3.70 \\
Tidak mengisi & 4.67 & & & \\
Pekerjaan $(\%)$ & & 38.46 & 12.20 & 18.52 \\
Karyawan & 23.36 & 30.77 & 2.44 & 3.70 \\
Wiraswasta & 13.08 & & 2.44 & 3.70 \\
Mahasiswa & 1.87 & 81.68 & 82.93 & 74.07 \\
Lainnya & 61.68 & & & \\
\hline & & & & \\
\hline
\end{tabular}

*). Gabungan = partisipan yang terdiri dari ayah, ibu, dan salah satu saudara dalam keluarga dengan ABK.

Tahap kedua adalah konstruksi skala. Hal ini dilakukan dengan uji validitas isi. Para ahli dalam bidang resiliensi dan kajian disabilitas sebanyak empat ahli pun melakukan penilaian terhadap aitem-aitem yang sudah dibuat. Para ahli tersebut telah melakukan beberapa penelitian dalam bidang yang relevan dengan penelitian ini, tiga ahli merupakan psikolog dalam bidang disabilitas dan satu orang doktor psikologi dalam bidang resiliensi. Setelah itu, dilakukan beberapa revisi berdasarkan saran dari para ahli bidang resiliensi keluarga baik dengan memperbaiki aitem-aitem yang sudah ada maupun menyusun aitem baru. Tahapan berikutnya, merupakan evaluasi aitemaitem secara kuantitatif. Pada tahap ini dilakukan pilot test guna menguji keterbacaan dari Skala Resiliensi Keluarga ABK. Kemudian, pengambilan data pun dilakukan dan analisis data.

Skala resiliensi keluarga dengan anak berkebutuhan khusus (Skala Resiliensi Keluarga ABK) disusun berdasarkan tiga dimensi utama (Walsh, 2002). Dimensi pertama yaitu sistem kepercayaan yang ada guna mengatasi tantangan dalam keluarga. Ringkasan indikator-indikator yang membentuk dimensi pertama ini dapat dilihat pada Tabel 2 berikut ini. 
Tabel 2

Indikator dari dimensi sistem kepercayaan.

\begin{tabular}{|c|c|}
\hline Aitem & Indikator \\
\hline \multirow{2}{*}{ No. $1-8$} & $\begin{array}{l}\text { Relasi dalam keluarga akan menjadi lebih kuat ketika krisis tersebut dipandang sebagai } \\
\text { tantangan. }\end{array}$ \\
\hline & $\begin{array}{l}\text { Penerimaan situasi yang tidak menyenangkan menjadi penting bagi keluarga untuk resilien. } \\
\text { Keluarga akan mencari pemahaman akan sebab akibat dari peristiwa ini. }\end{array}$ \\
\hline \multirow{5}{*}{ No. $9-22$} & Harapan, penting dalam memperbaiki hubungan yang bermasalah. \\
\hline & $\begin{array}{l}\text { Keluarga perlu menyadari kekuatan dan potensi yang mereka miliki untuk dapat mengatasi } \\
\text { rasa gagal dan menyalahi diri sendiri }\end{array}$ \\
\hline & Membuka kemungkinan adanya berbagai kesempatan untuk keluar dari permasalahan \\
\hline & $\begin{array}{l}\text { Persepsi keluarga terhadap kemampuan yang dimiliki untuk mengatasi masalah atau } \\
\text { tantangan }\end{array}$ \\
\hline & $\begin{array}{l}\text { Resiliensi menuntut seseorang untuk menerima keterbatasan dari kekuatan yang dimiliki } \\
\text { oleh keluarga, memahami situasi apa yang bisa dikontrol dan yang tidak dan melakukan } \\
\text { usaha yang optimal. }\end{array}$ \\
\hline \multirow{3}{*}{ No. $23-31$} & $\begin{array}{l}\text { Keluarga dengan spiritualitas tinggi lebih mampu untuk mengatasi masalah yang } \\
\text { dihadapinya }\end{array}$ \\
\hline & Adanya role model, ada cita-cita atau impian. \\
\hline & Ada proses perubahan yang terjadi. \\
\hline
\end{tabular}

Dimensi kedua adalah pola hubungan yang ada dalam keluarga. Ringkasan indikator-indikator yang membentuk dimensi pertama ini dapat dilihat pada Tabel 3 berikut ini.

Tabel 3

Indikator dari pimensi pola hubungan keluarga.

\begin{tabular}{|c|c|}
\hline Aitem & Indikator \\
\hline \multirow{5}{*}{ No. $32-45$} & $\begin{array}{l}\text { Kapasitas untuk berubah adalah hal penting dalam keluarga khususnya dalam kondisi } \\
\text { stress. }\end{array}$ \\
\hline & Keluarga saling terikat namun juga menghargai keunikan individu. \\
\hline & Keluarga yang berfungsi dengan baik memiliki anggota keluarga yang saling mendukung \\
\hline & $\begin{array}{l}\text { Rutinitas dan ritual memelihara rasa keberlangsungan dari waktu ke waktu, masa lalu, } \\
\text { sekarang, dan yang akan datang melalui tradisi yang dialami bersama dan harapan. }\end{array}$ \\
\hline & Mengusahakan hubungan dan rekonsiliasi dari hubungan \\
\hline \multirow{4}{*}{ No. $46-53$} & $\begin{array}{l}\text { Keluarga besar dan jejaring sosial menyediakan bantuan praktis, dukungan emosional, dan } \\
\text { juga informasi }\end{array}$ \\
\hline & Dukungan dari lingkungan luar dengan relasi seperti mentor \\
\hline & Perlu diketahui kondisi finansial dan dukungan antara pekerjaan dengan keluarga \\
\hline & Dukungan dari lingkungan yang lebih luas \\
\hline
\end{tabular}

Sedangkan dimensi ketiga adalah cara komunikasi dalam keluarga. Ringkasan indikator-indikator yang membentuk dimensi pertama ini dapat dilihat pada Tabel 4. 
Tabel 4

Indikator dari dimensi cara komunikasi dalam keluarga.

\begin{tabular}{|c|c|}
\hline Aitem & Indikator \\
\hline \multirow{3}{*}{ No. $54-60$} & Kejelasan dalam komunikasi penting untuk berfungsinya keluarga secara efektif. \\
\hline & $\begin{array}{l}\text { Penting untuk mengjklarifikasi situasi sejelas mungkin. Situasi kemalangan yang sedang } \\
\text { dihadapi juga harus diklarifikasi maknanya bagi semua anggota keluarga. }\end{array}$ \\
\hline & $\begin{array}{l}\text { Pada beberapa situasi kemalangan, masing-masing anggota keluarga secara terbuka } \\
\text { membicarakan situasi tersebut. }\end{array}$ \\
\hline \multirow{4}{*}{ No. $61-65$} & $\begin{array}{l}\text { Anggota keluarga dapat menunjukkan dan bertoleransi terhadap berbagai macam } \\
\text { perasaan baik positif maupun negatif. }\end{array}$ \\
\hline & $\begin{array}{l}\text { Anggota keluarga dapat menunjukkan perasaan yang berbeda pada saat yang berbeda } \\
\text { pula. }\end{array}$ \\
\hline & Keluarga tidak saling menyalahkan. \\
\hline & $\begin{array}{l}\text { Berbagi cerita tentang kehidupan dengan humor maupun dengan belas kasihan dapat } \\
\text { mendekatkan keluarga. }\end{array}$ \\
\hline \multirow{6}{*}{ No. $66-71$} & $\begin{array}{l}\text { Keluarga yang resilien memiliki kemampuan untuk mengatur dan menyelesaikan } \\
\text { konflik serta masalah dengan berkolaborasi antar anggotanya. }\end{array}$ \\
\hline & Curah pendapat secara kolaboratif. \\
\hline & Keluarga yang berfungsi dengan baik dapat menyelesaikan masalah dengan efisien. \\
\hline & Pengambilan langkah konkrit \\
\hline & Belajar dari kegagalan dan kesalahan yang dilakukan \\
\hline & $\begin{array}{l}\text { Keluarga memiliki alternatif penyelesaian masalah, melakukan apa yang sudah } \\
\text { disepakati dan menerima apa yang tidak dapat diubah }\end{array}$ \\
\hline
\end{tabular}

Ada pun definisi resiliensi keluarga yang gunakan dalam penelitian ini adalah keyakinan sebagai anggota keluarga dengan ABK untuk menerima keterbatasan dari kekuatan yang dimiliki oleh anggota keluarganya dan melakukan usaha yang optimal dalam mengembangkan pola interaksi juga komunikasi dalam keluarga sehingga keluarga mendapatkan dukungan dalam melewati tantangan kehidupan, membangun kembali kegembiraan dan kenyamanan dalam berelasi (Walsh, 2002). 71 pernyataan disusun dengan empat pilihan jawaban sangat tidak sesuai (diberi skor 1), tidak sesuai (diberi skor 2), sesuai (diberi skor 3), dan sangat sesuai (diberi skor 4). Responden diminta untuk memberikan tanda centang sesuai dengan keadaan yang sebenarnya dilihat, dirasakan, dan dipikirkan. Responden diyakinkan bahwa tidak ada jawaban benar atau salah.

Dari 71 aitem yang dibuat, ada delapan aitem unfavorable, yaitu aitem nomor 8, 16, 19, 22, 29, 31, 63, dan 64. Pada umumnya, cara penyekoran adalah memberikan skor pada pilihan yang diberi tanda centang oleh responden: sangat tidak sesuai (skor 1), tidak sesuai (skor 2), sesuai (skor 3), dan sangat sesuai (skor 4). Penyekoran yang terbalik diberikan pada delapan aitem unfavorable, sehingga ketika responden memberikan tanda centang pada pilihan sangat tidak sesuai (skor 4), tidak sesuai (skor 3), sesuai (skor 2), dan sangat sesuai (skor 1).

Dalam usaha mengembangkan Skala Resiliensi Keluarga ABK ini, skala diberkan kepada keluarga yang memiliki ABK. Ada pun yang menjadi responden dari tiap keluarga adalah ayah, ibu, dan saudara dari ABK. Data yang terkumpul kemudian 
dianalisis dalam empat tahapan: respon ayah, respon ibu, respon saudara, dan respon gabungan (ayah, ibu, dan saudara).

Analisis pertama yang dilakukan adalah dengan mencari koefisien corrected item-total correlation dari setiap aitem. Seletah itu dicari 35 aitem terbaik dari setiap kelompok responden (ayah, ibu, dan saudara) juga dari responden secara keseluruhan (gabungan). Responden gabungan diperlukan untuk mendapatkan skala dengan aitemaitem umum yang bisa digunakan untuk pengukuran lintas peran mulai dari ayah, ibu, atau pun salah satu saudara dalam keluarga dengan ABK. Dari tiap kelompok responden tersebut, dicari lagi aitem-aitem yang dimiliki oleh setiap kelompok responden. Aitemaitem inilah yang membentuk versi final dari Skala Resiliensi Keluarga ABK.

Setelah aitem-aitem versi final didapatkan, peneliti menguji validitas dengan melakukan exploratory factor analysis (EFA). Analisis komponen utama digunakan sebagai metode ekstraksi dan varimax dengan normalisasi Kaiser sebagai metode rotasi. Hal ini untuk menentukan jumlah dimensi yang sebenarnya dimiliki oleh alat tes ini. Selanjutnya, dilakukan analisa confirmatory factor analysis (CFA) dengan cara measurement model. CFA dalam penelitian ini dilakukan untuk menguji aitem-aitem yang sudah berkelompok menjadi sebuah faktor dengan metode EFA itu valid dalam mengukur konstruknya tersebut atau tidak. Peneliti menguji kecocokan data (data fit) dengan model yang dibentuk berdasarkan analisis sebelumnya (EFA) untuk dijadikan acuan dalam melakukan CFA. Untuk menentukan model fit, $\mathrm{Hu}$ dan Bentler (1999) menyarankan Tucker-Lewis Index $(\mathrm{TLI}=\mathrm{NNFI})$ dan nilai Comparative Fit Index (CFI) sama atau di atas .95 dan Root Mean Square Error of Approximation (RMSEA) nilai kurang dari atau sama dengan .06. Semua analisis dilakukan dengan bantuan program olah data dengan menggunakan program IBM SPSS Statistics 22 dalam melakukan analisis aitem dan EFA, serta LISREL 8.80 untuk melakukan CFA.

\section{Hasil dan Pembahasan}

Dalam mengembangkan skala ini, disusun 71 pernyataan. Dari 71 pernyataan tersebut dipilih 35 pernyataan dengan nilai corrected item total correlation tertinggi, baik dari partisipan ayah, ibu, saudara, maupun gabungan ketiganya. Dari hasil analisis aitem, jangkauan corrected item total correlation dari partisipan kelompok ayah adalah $0.51-0.71$. Untuk partisipan kelompok ibu, jangkauan corrected item total correlation antara $.42-0.48$. Selanjutnya, jangkauan corrected item total correlation untuk partisipan kelompok saudara antara $0.49-0.89$. Kemudian, jangkauan corrected item total correlation dari partisipan gabungan (ayah, ibu, dan saudara) adalah sebesar 0.44 0.7. Detil mengenai tiap koefisien corrected item total correlation per dimensi tersedia pada Lampiran 1. Dari 35 aitem tersebut, peneliti memilih 15 aitem lintas kelompok partisipan dengan corrected item total correlation tertinggi.

Setelah itu, dilakukan analisis lebih lanjut dari 15 aitem tersebut dengan Exploratory Factor Analysis (EFA). Dari hasil EFA, didapatkan tiga faktor (dimensi) utama. Faktor ini dinamakan penerimaan adanya ABK dalam keluarga, pengelolaan tantangan keluarga dengan ABK, dan akses perolehan dukungan terhadap keluarga dengan ABK. Reliabilitas skala resiliensi keluarga dengan anak berkebutuhan khusus, memiliki 15 aitem penyataan dengan alpha $.92(M=47.50, \mathrm{SD}=6.22)$. Informasi detil mengenai EFA dan reliabilitas dapat dilihat pada Tabel 5. 
Tabel 5

Hasil exploratory factor analysis

\begin{tabular}{|c|c|c|c|}
\hline Pernyataan & Faktor 1 & Faktor 2 & Faktor 3 \\
\hline I26 & .748 & & \\
\hline $\mathrm{I} 28$ & .632 & & \\
\hline $\mathrm{I} 33$ & .573 & & \\
\hline $\mathrm{I} 36$ & .753 & & \\
\hline $\mathrm{I} 45$ & .807 & & \\
\hline I46 & .731 & & \\
\hline I47 & .576 & & \\
\hline $\mathrm{I} 48$ & .731 & & \\
\hline $\mathrm{I} 58$ & & .765 & \\
\hline I59 & & .704 & \\
\hline I60 & & .747 & \\
\hline I62 & & .688 & \\
\hline I65 & & & .784 \\
\hline I67 & & & .815 \\
\hline I69 & & & .530 \\
\hline Eigenvalues & 7.34 & 1.57 & 1.5 \\
\hline Persentase varians & 48.92 & 10.44 & 10.01 \\
\hline Reliabilitas & .91 & .83 & .69 \\
\hline
\end{tabular}

Keterangan: Faktor 1 = Penerimaan ABK di keluarga, Faktor 2 = Pengelolaan tantangan keluarga dengan ABK, dan Faktor 3 = Akses dukungan terhadap keluarga dengan ABK.

Versi akhir dari skala ini dapat diperoleh dengan menghubungi penulis.

Meski pada EFA menghasilkan tiga faktor, namun aitem-aitem yang tergabung dalam faktor-faktor (dimensi-dimensi) tersebut berbeda dari rancangan aitem-aitem pada kisi-kisi. Dengan demikian, diberikan penamaan baru pada dimensi-dimensi dari konstruk resiliensi keluarga dengan anak berkebutuhan khusus. Penamaan dimensi ini didasarkan pada isi dari aitem-aitem yang tergabung dalam satu faktor. Berikut ini definisi dari setiap dimensi. Dimensi pertama, penerimaan adanya ABK dalam keluarga (dimensi penerimaan) didefinisikan sebagai lensa yang digunakan sebagai anggota keluarga dengan ABK untuk menerima keterbatasan dari kekuatan yang dimiliki oleh keluarga, memahami situasi apa yang bisa dikontrol dan yang tidak, serta melakukan usaha yang optimal melihat dunia sehingga dapat melewati tantangan kehidupan, membangun kembali kehidupan, dan memperbaiki harapan lama yang sempat hilang. Kemudian untuk dimensi kedua, pengelolaan tantangan keluarga dengan ABK (dimensi pengelolaan) adalah pola interaksi dalam keluarga inti maupun keluarga besar termasuk di dalamnya dukungan dalam hal praktis, emosional, informasi, dan finansial. Dimensi terakhir, akses perolehan dukungan terhadap keluarga dengan ABK (dimensi dukungan) adalah pola dan proses komunikasi dalam keluarga yang terbuka, mengklarifikasi situasi sejelas mungkin, bertoleransi terhadap berbagai macam perasaan baik positif maupun negatif sehingga terjadi kehangatan, suasana optimis, kegembiraan dan kenyamanan dalam berelasi.

Confirmatory Factor Analysis (CFA) selanjutnya dilakukan dengan 15 aitem pernyataan dengan pembagian faktor sesuai dengan hasil EFA. CFA dengan model tiga faktor ini menghasilkan $\chi^{2} / \mathrm{df}=1.02, \mathrm{p}=.43$, RMSEA $=.01, \mathrm{CFI}=1.00$, TLI $=1.00$, GFI $=.90$. Model ini fit dengan data. Hal ini berarti aitem-aitem yang sudah 
berkelompok menjadi tiga faktor (penerimaan, pengelolaan, dan dukungan) dengan metode EFA terkonfirmasi mengukur konstruk resiliensi keluarga dengan anak berkebutuhan khusus.

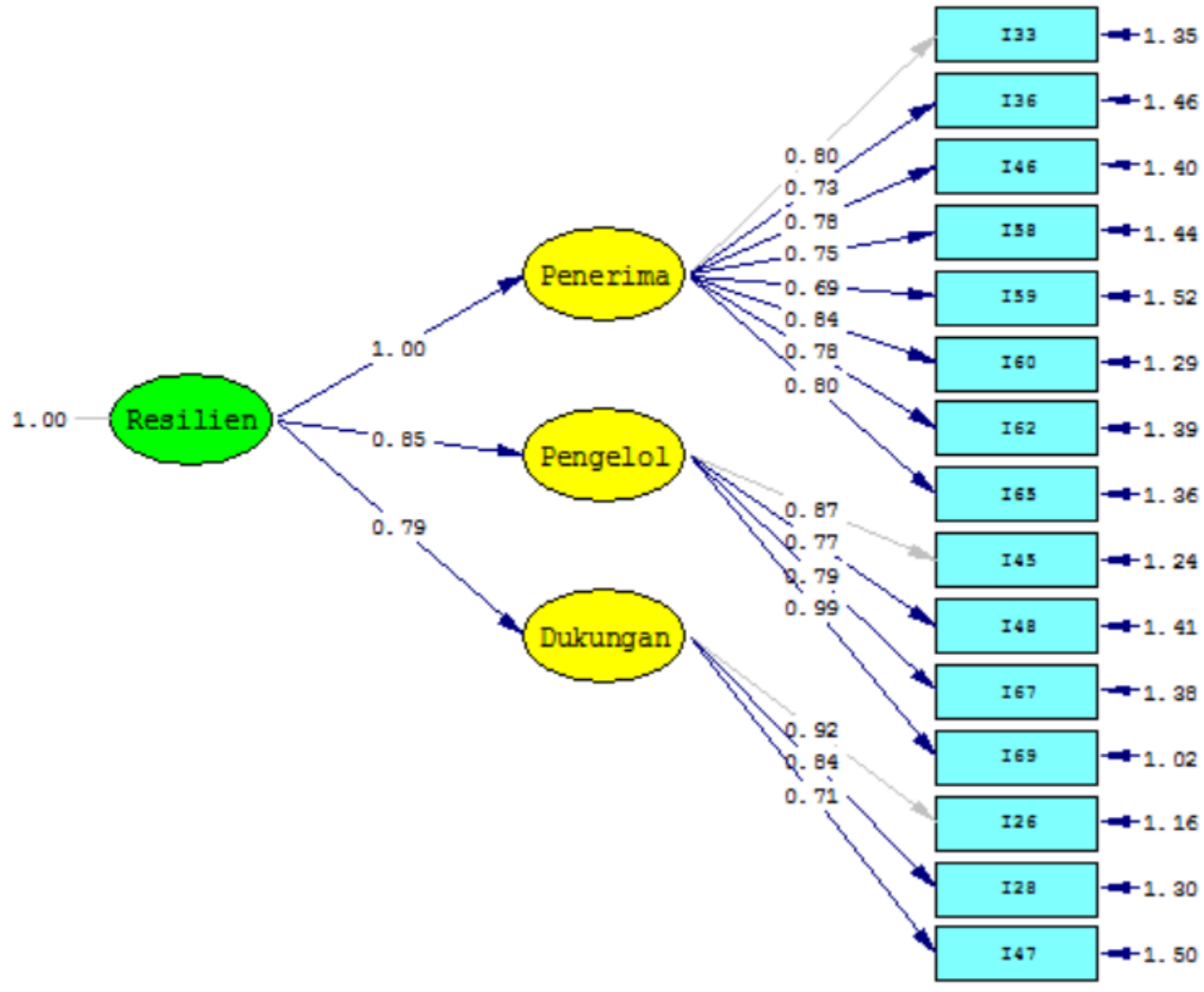

Chi-3quare $=88.66, d f=87, P-v a l u e=0.43030$, RMSEA $=0.013$

Gambar 1. Hasil Confirmatory Factor Analysis dengan model tiga faktor

Pengembangan skala resiliensi keluarga dengan anak berkebutuhan khusus (Skala Resiliensi Keluarga ABK) melibatkan partisipan dengan peran ayah, ibu, dan saudara kandung dalam penelitian ini. Dari 71 aitem, telah terpilih 15 aitem terbaik lintas peran (ayah, ibu, dan saudara) guna mengukur resiliensi keluarga ABK. Secara reliabilitas, skala ini memiliki reliabilitas yang tinggi. Dari segi teoritis juga data, terbukti bahwa skala ini memiliki tiga faktor (dimensi), yang ketiganya mengukur satu konstruk, yaitu resiliensi keluarga ABK. Hal itu sesuai dengan teori resiliensi keluarga yang dikemukakan oleh Walsh (2002). Walaupun Walsh (2002) mengembangkan teori resiliensi keluarga secara umum, namun dari beberapa penelitian terbukti dapat digunakan untuk menjelaskan resiliensi keluarga dalam situasi krisis atau disadvantage (Sixbey, 2005). Hal itu terlihat juga dalam penelitian ini. Skala ini reliabel dan valid untuk mengukur resiliensi ABK.

Dalam penelitian ini, peneliti mendapatkan data dari 41 keluarga dengan anak berkebutuhan khusus. Hal ini bisa menjadi keterbatasan namun juga kekuatan dikarenakan sampel yang didapatkan adalah related sample: ayah, ibu, dan saudara kandung. Meminta tiga orang dalam satu keluarga untuk mengisi, cukup sulit. Selain itu, terkadang dalam keluarga tersebut, masih ada salah satu atau dua dari mereka (ayah, 
ibu, atau saudara kandung) yang masih menolak fakta bahwa ada anak mereka yang berkebutuhan khusus sehingga tidak bersedia mengisi skala.

Ada pun keterbatasan dari penelitian ini, partisipan tinggal di Jakarta, kota metropolitan. Hal ini kemungkinan memberikan keuntungan dalam dimensi dukungan. Akses informasi yang sudah relatif terbuka sehingga memungkinkan keluarga ABK mengetahui akses untuk memperoleh dukungan dan mengklarifikasi situasi sejelas mungkin sehingga dapat melakukan usaha yang optimal guna melewati tantangan. Keluarga ABK menghadapi tantangan yang besar dalam menemukan layanan yang sesuai dengan kebutuhan anak seperti sekolah, pusat terapi, maupun layanan kesehatan (Hartshorne, Schafer, Startton, \& Nacarato, 2013). Sehingga penelitian selanjutnya dapat melakukan penelitian, selain di kota dipertimbangkan untuk melakukan penelitian di pedesaan. Hal ini guna mengetahui apakah skala ini bisa diterapkan di area geografis yang berbeda.

Keterbatasan lain dari penelitian ini adalah standarisasi. Besar sampel yang diperoleh kurang adekuat untuk pembuatan norma skala ini. Penelitian selanjutnya mengenai resiliensi keluarga $\mathrm{ABK}$ ini didorong untuk menggunakan skala yang kami buat sehingga data senantiasa dapat diperoleh guna pembuatan norma.

Terlepas dari keterbatasan yang ada, skala resiliensi keluarga ABK dengan 15 aitem ini sudah siap digunakan. Skala ini sudah bisa digunakan sebagai instrumen bagi penelitian dalam bidang resiliensi keluarga khususnya yang memiliki ABK.

\section{Simpulan}

Skala Resiliensi Keluarga dengan Anak Berkebutuhan Khusus ini terdiri dari 15 aitem dengan 3 dimensi, yaitu penerimaan, pengelolaan, dan dukungan. Skala ini valid berdasarkan metode faktor analisis, baik exploratory factor analysis maupun confimatory factor analysis dan memiliki reliabilitas yang tinggi. Oleh karenanya, skala ini dapat digunakan dalam asesmen, penelitian, maupun intervensi pada keluarga yang memiliki anak dengan kebutuhan khusus.

\section{Daftar Pustaka}

Benard, B. (2004). Resiliency: What we have learned: WestEd.

Burgess, A. F., \& Gutstein, S. E. (2007). Quality of life for people with Autism: raising the standard for evaluating successful outcomes. Child and Adolescent Mental Health, 12(2), 80-86. doi:10.1111/j.1475-3588.2006.00432.x

Cappe, E., Wolff, M., Bobet, R., \& Adrien, J. L. (2011). Quality of life: a key variable to consider in the evaluation of adjustment in parents of children with autism spectrum disorders and in the development of relevant support and assistance programmes. Quality of Life Research, 20(8), 1279-1294. doi:10.1007/s11136011-9861-3

Cicchetti, D., \& Cohen, D. J. . (1995). Developmental psychopathology: Risk, disorder, and adaptation. New York: Wiley. 
Davis, N. J. (1999). Resilience \& School Violence Prevention: Research-based program, National Mental Health Information Centre. Retrieved from http://www.mentalhealth.samhsa.gov/schoolviolence.

Frain, M. P., Berven, N. L., Tschopp, M. K., Lee, G. K., Tansey, T., \& Chronister, J. (2007). Use of the resiliency model of family stress, adjustment and adaptation by rehabilitation counselors. Journal of Rehabilitation, 73(3), 18-25.

Goldman, L. (2006). Raising our children to be resilient. New York

Taylor \& Francis Group.

Grotberg, E. H. (2003). Promoting resilience, 8 (4).

Gupta, V. B. (2007). Comparison of parenting stress in different developmental disabilities. Journal of Developmental and Physical Disabilities, 19(4), 417-425. doi:10.1007/s10882-007-9060-x

King, G., Law, M., King, S., Rosenbaum, P., Kertoy, M. K., \& Young, N. L. (2003). A conceptual model of the factors affecting the recreation and leisure participation of children with disabilities. Physical and Occupational Therapy in Pediatrics, 23(1), 63-90. doi:10.1300/j006v23n01_05

Kusumastuti, P., Pradanasari, R., \& Ratnawati, A. (2014). The problems of people with disability in Indonesia and what is being learned from the World Report on Disability. American Journal of Physical Medicine and Rehabilitation, 93(1 Suppl 1), S63-67. doi:10.1097/PHM.0000000000000025

Maulipaksi, D. (2017). Sekolah Inklusi dan Pembangunan SLB Dukung Pendidikan Inklusi. Retrieved from https://www.kemdikbud.go.id/main/blog/2017/02/sekolah-inklusi-danpembangunan-slb-dukung-pendidikan-inklusi

Migerode, F., Maes, B., Buysse, A., \& Brondeel, R. (2012). Quality of life in adolescents with a disability and their parents: The mediating role of social support and resilience. Journal of Developmental and Physical Disabilities, 24(5), 487-503. doi:10.1007/s10882-012-9285-1

Riany, Y. E., Cuskelly, M., \& Meredith, P. (2016). Cultural beliefs about Autism in Indonesia. International Journal of Disability Development and Education, 63(6), 623-640. doi:10.1080/1034912x.2016.1142069

Santoso, T. B., Ito, Y., Ohshima, N., Hidaka, M., \& Bontje, P. (2015). Resilience in daily occupations of Indonesian mothers of children with Autism Spectrum Disorder. American Journal of Occupational Therapy, 69(5), 6905185020p6905185021-6905185028. doi:10.5014/ajot.2015.017566

Schieve, L. A., Blumberg, S. J., Rice, C., Visser, S. N., \& Boyle, C. (2007). The relationship between Autism and parenting stress. Pediatrics, 119 Suppl 1(Supplement 1), S114-121. doi:10.1542/peds.2006-2089Q

Scorgie, K., Wilgosh, L., \& Sobsey, D. (2004). The Experience of Transformation in Parents of Children with Disabilities: Theoretical Considerations. Developmental Disabilities Bulletin, 32(1), 84-110. 
Seligman, M., \& Darling, R. B. . (1997). Ordinary families, special children: a systems approach to childhood disability. New York: Guilford Press.

Sixbey, M. T. (2005). Development of the family resilience assessment scale to identify family resilience constructs. University of Florida Florida,

Suzuki, K., Kobayashi, T., Moriyama, K., Kaga, M., \& Inagaki, M. (2013). A Framework for resilience research in parents of children with Developmental Disorders. Asian Journal of Human Services, 5(0), 104-111. doi:10.14391/ajhs.5.104

Walsh, F. (2002). A family resilience framework: Innovative practice applications. Family Relations, 51(2), 130-137. doi:DOI 10.1111/j.1741-3729.2002.00130.x 
Lampiran 1

Analisis Aitem dari Tiap Kelompok Partisipan

\begin{tabular}{|c|c|c|c|c|c|c|c|}
\hline $\begin{array}{l}\text { Semua } \\
\text { partisipan }\end{array}$ & $\begin{array}{l}\text { Corrected } \\
\text { Item-Total } \\
\text { Correlation }\end{array}$ & Ayah & $\begin{array}{l}\text { Corrected } \\
\text { Item-Total } \\
\text { Correlation }\end{array}$ & Ibu & $\begin{array}{l}\text { Corrected } \\
\text { Item-Total } \\
\text { Correlation }\end{array}$ & Saudara & $\begin{array}{l}\text { Corrected } \\
\text { Item-Total } \\
\text { Correlation }\end{array}$ \\
\hline $\mathrm{I} 2$ & .56 & 12 & .62 & $\mathrm{I} 2$ & .67 & I9 & .50 \\
\hline I5 & .51 & I4 & .57 & I5 & .57 & I13 & .50 \\
\hline I9 & .46 & I5 & .61 & I6 & .51 & I15 & .81 \\
\hline I10 & .45 & $\mathrm{I} 12$ & .54 & I9 & .53 & I 26 & .55 \\
\hline I15 & .51 & $\mathrm{I} 20$ & .55 & $\mathrm{I} 10$ & .57 & $\mathrm{I} 28$ & .50 \\
\hline $\mathrm{I} 20$ & .48 & $\mathrm{I} 23$ & .68 & I1 1 & .49 & I29 & .66 \\
\hline $\mathrm{I} 25$ & .47 & I24 & .62 & I14 & .64 & I30 & .55 \\
\hline $\mathrm{I} 26$ & .62 & $\mathrm{I} 25$ & .61 & $\mathrm{I} 20$ & .51 & I31 & .49 \\
\hline $\mathrm{I} 28$ & .58 & I26 & .71 & $\mathrm{I} 24$ & .50 & I33 & .82 \\
\hline I33 & .71 & I27 & .68 & I25 & .43 & I34 & .76 \\
\hline I35 & .51 & I 28 & .64 & I26 & .65 & I35 & .83 \\
\hline I36 & .70 & $\mathrm{I} 33$ & .59 & $\mathrm{I} 28$ & .66 & I36 & .82 \\
\hline I41 & .58 & I36 & .69 & I33 & .68 & $\mathrm{I} 40$ & .49 \\
\hline I42 & .48 & I38 & .51 & I34 & .55 & I41 & .78 \\
\hline I43 & .55 & I41 & .62 & I36 & .57 & I42 & .74 \\
\hline I45 & .55 & I43 & .55 & I37 & .51 & I43 & .74 \\
\hline I46 & .65 & I44 & .57 & I42 & .49 & I 45 & .52 \\
\hline I47 & .58 & I 45 & .69 & I 45 & .55 & I 46 & .81 \\
\hline I 48 & .54 & I 46 & .65 & I 46 & .46 & I 47 & .81 \\
\hline I49 & .53 & I47 & .51 & I47 & .43 & I48 & .55 \\
\hline I50 & .48 & I 48 & .64 & I 48 & .50 & I49 & .69 \\
\hline I54 & .52 & I56 & .66 & I49 & .46 & I50 & .82 \\
\hline I56 & .63 & I57 & .69 & I54 & .47 & I51 & .62 \\
\hline I57 & .63 & I58 & .69 & I55 & .42 & I52 & .64 \\
\hline I58 & .69 & I59 & .64 & I58 & .42 & I54 & .74 \\
\hline I59 & .64 & I60 & .63 & I59 & .42 & I56 & .79 \\
\hline I60 & .66 & I61 & .70 & I60 & .46 & I57 & .80 \\
\hline I62 & .69 & I62 & .65 & I61 & .44 & I58 & .89 \\
\hline I65 & .63 & I65 & .62 & I62 & .56 & I59 & .80 \\
\hline I66 & .44 & I66 & .60 & I65 & .42 & I60 & .83 \\
\hline I67 & .52 & I67 & .58 & I67 & .48 & I62 & .85 \\
\hline I68 & .47 & I68 & .52 & I68 & .48 & I64 & .65 \\
\hline I69 & .72 & I69 & 67 & I69 & .60 & I65 & .77 \\
\hline I70 & .46 & I70 & .57 & I70 & .51 & I67 & .58 \\
\hline I71 & .54 & I71 & .60 & I71 & .55 & I69 & .84 \\
\hline
\end{tabular}

*aitem yang disorot merupakan aitem yang lolos pada semua kelompok partisipan. 